\title{
Eksplorasi Sikap Pembaca terhadap Wacana Kebijakan Program Pendidikan Kejuruan Empat Tahun
}

\section{Exploration of Readers' Attitudes towards the Discourse of the Four-Year Vocational Education Program Policy}

\author{
Elga Andina \\ elga.andina@dpr.go.id \\ Pusat Penelitian, Badan Keahlian DPR RI \\ JI. Jenderal Gatot Subroto, Senayan, Jakarta, 10270
}

Naskah diterima: 7 September 2020 | Naskah direvisi: 12 Oktober 2020 | Naskah diterbitkan: 31 Desember 2020

\begin{abstract}
The government plans to change the length of education for several vocational high schools (SMK) to four years to prepare fully equipped graduates with operational techniques. The purpose of this study is to explore the readers' attitudes towards the discourse on the policy of a four-year vocational education program. This research uses secondary data collected from readers' comments on published discourses on electronic media from June 11 to June 15, 2020, completed with interviews with the local government offices, SMK, and Special Region of Yogyakarta's Chamber of Commerce (KADIN). The content analysis techniques applied to the data resulted in the four-year education program's discourses challenged three main things: employment, financing, and the impact on the age of graduates. These three issues can be managed if the development of SMK is appropriate and in line with the needs of business and industry (DUDI). However, the link and match process between SMK and DUDI is still not optimal due to the provincial government's lack of role as the holder of vocational education authority in the region. Strengthening responsibility and concrete work, especially from the provincial education office, is the key to vocational education development. Without improving government performance, the goal of improving the quality of education by adding one year is futile. The government must be able to ensure graduate employment by requiring SMKs to form partnerships with DUDI, a guarantee of education funding until graduation, and skills that are equivalent to graduates' age.
\end{abstract}

Keywords: four-year education program; link and match; vocational education; vocational high school

Abstrak: Pemerintah merencanakan mengubah lama pendidikan beberapa SMK menjadi empat tahun dalam rangka mempersiapkan lulusan yang lebih menguasai teknik operasional secara utuh. Tujuan studi ini adalah mengeksplorasi sikap masyarakat terhadap wacana kebijakan program pendidikan kejuruan dari tiga menjadi empat tahun. Penelitian ini menggunakan data sekunder yang berasal dari komen pembaca terhadap pemberitaan wacana di media elektronik dari tanggal 11 s.d. 15 Juni 2020, dilengkapi dengan wawancara dengan pemerintah daerah, SMK, dan KADIN Provinsi Daerah Istimewa Yogyakarta. Berdasarkan analisis konten atas data tersebut ditemukan wacana program pendidikan empat tahun menggugat tiga hal pokok: kebekerjaan, pembiayaan, dan dampaknya terhadap usia lulusan. Ketiga isu 
tersebut dapat ditata jika pengembangan SMK sesuai dan sejalan dengan kebutuhan dunia usaha dan/atau dunia industri (DUDI). Namun, proses link and match SMK dengan DUDI masih belum optimal, karena kurangnya peran pemerintah provinsi sebagai pemegang kewenangan pendidikan kejuruan di daerah. Penguatan tanggung jawab dan kerja konkret terutama dari dinas pendidikan provinsi merupakan kunci pengembangan pendidikan kejuruan karena tanpa perbaikan kinerja pemerintah maka tujuan peningkatan kualitas pendidikan dengan menambah satu tahun menjadi siasia. Pemerintah harus mampu memastikan kebekerjaan lulusan dengan mensyaratkan SMK untuk menjalin kemitraan dengan DUDI, jaminan pembiayaan pendidikan hingga lulus, dan keterampilan yang sepadan dengan usia lulusan.

Kata Kunci: link and match; masa pendidikan empat tahun; pendidikan kejuruan; SMK

\section{Pendahuluan}

Pada tanggal 11 Juni 2020 Kementerian Pendidikan dan Kebudayaan (Kemendikbud) mengumumkan akan mengubah lama pendidikan beberapa sekolah menengah kejuruan (SMK) yang sebelumnya tiga tahun menjadi empat tahun (Kumparan, 2020a). Dengan ditambah satu tahun maka siswa diharapkan menguasai teknik operasional secara utuh, juga akan meningkatkan citra profesionalitas lulusan SMK di dunia usaha dan/atau dunia industri (DUDI). Munculnya wacana perubahan lama studi ini merupakan salah satu upaya untuk menyatukan kurikulum SMK dengan kebutuhan DUDI atau lebih sering diistilahkan dengan link and match. Belakangan Kemendikbud memperkenalkan istilah "kawin massal" untuk menjelaskan upaya menyesuaikan hasil belajar siswa SMK dengan pasar kerja ini.

Kebijakan ini pernah dikenal dengan istilah Pendidikan Sistem Ganda (PSG) yang dimulai pada tahun 1997 dengan Kepmen No. 323/U/1997. Langkah ini upaya pertama pelibatan DUDI dalam pendidikan vokasi (Kemendikbud, 2016: 15). Dalam sistem ini model pendidikan sekolah yang sebelumnya banyak dipakai dalam pendidikan zaman kolonial digabungkan dengan model magang sehingga dianggap ideal untuk meningkatkan relevansi dan efisiensi SMK karena membekali siswa SMK dengan keterampilan yang dibutuhkan di DUDI.
Penyelenggaraan sistem ini dilakukan dengan: (1) Pelaksanaan kegiatan gebyar pendidikan vokasi; (2) Penandatanganan kerja sama sekolah dengan DUDI; (3) Pembentukan organisasi intern di sekolah; dan (4) Kunjungan guru-guru secara reguler ke DUDI.

Untuk menjembatani proses pembelajaran sekolah dengan kebutuhan DUDI pernah dibentuk Majelis Pendidikan Kejuruan dan Majelis Pendidikan Vokasi Provinsi melalui Surat Keputusan Bersama Departemen Pendidikan dan Kebudayaan dan Kamar Dagang dan Industri Indonesia tentang pembentukan Majelis Pendidikan Kejuruan dengan Nomor 0217/U/1994 dan 044/SKEP/KU/VIII/94. Meskipun begitu, lembaga tersebut tidak aktif sementara surat keputusan masih berlaku $(\mathrm{PH}, 2013$ : 15).

Setelah hampir sembilan tahun ide penyelarasan pendidikan kejuruan dengan kebutuhan DUDI belum mengalami perkembangan yang berarti. Lulusan SMK masih menjadi lulusan dengan tingkat pengangguran terbuka (TPT) tertinggi setiap tahun. Hal ini memaksa Kemendikbud mengevaluasi dan merevisi pola pengembangan SMK hingga Presiden menerbitkan Instruksi Presiden Nomor 9 Tahun 2016 tentang Revitalisasi Sekolah Menengah Kejuruan. Revitalisasi SMK harus dilakukan terhadap: (1) Kurikulum; (2) Guru dan tenaga kependidikan; (3) Kerja sama dengan DUDI; (4) Sertifikasi dan akreditasi; dan (5) Sarpras dan kelembagaan (Dit.PSMK, 2019a: 179-186). 
Melalui Inpres ini Pemerintah ingin mendorong semua kementerian dan stakeholders terkait untuk meningkatkan kualitas dan daya saing SMK sesuai dengan kewenangan masing-masing, juga mengakselerasi penyusunan peta kebutuhan tenaga kerja bagi lulusan SMK dengan berpedoman pada peta jalan pengembangan SMK. Selama ini terjadi saling lempar tanggung jawab mengenai siapa yang seharusnya memiliki peta kebutuhan sumber daya manusia lulusan SMK, apakah itu pemerintah ataukah dunia pendidikan dan DUDI. Padahal, dengan adanya pemetaan yang komprehensif akan memudahkan strategi penyerapan tenaga kerja lulusan SMK.

Yang terjadi di lapangan adalah masih rendahnya penyerapan tenaga kerja lulusan SMK. Kondisi ini diperparah dengan cepatnya perubahan kebutuhan tenaga kerja yang perlu dihadapi dengan kesiapan dunia pendidikan untuk menyesuaikan dengan tuntutan zaman. Pada tahun 2016 saja sudah terlihat penurunan permintaan lulusan SMK pada bidang keahlian bisnis dan manajemen (lihat Tabel 1). Padahal, jurusan ini merupakan salah satu yang paling diminati masyarakat.

Tabel 1.

Bidang Keahlian dan Peluang Kebutuhan Tenaga Kerja, Tahun 2016

\begin{tabular}{lrrr}
\hline \multicolumn{1}{c}{ Bidang Keahlian } & Lulusan SMK & $\begin{array}{c}\text { Peluang } \\
\text { Kebutuhan } \\
\text { Tenaga Kerja }\end{array}$ & $\begin{array}{c}\text { Kelebihan (+)/ } \\
\text { Kekurangan (-) }\end{array}$ \\
\hline Teknologi dan Rekayasa & 441.561 & 811.644 & 170.083 \\
Energi dan Pertumbuhan & 3.486 & 27.008 & 23.522 \\
Teknologi Informasi dan Komunikasi & 277.545 & 327.813 & 50.268 \\
Kesehatan dan Pekerjaan Sosial & 60.944 & 68.245 & 394.473 \\
Agribisnis dan Agroteknologi & 52.319 & 445.792 & 393.473 \\
Kemaritiman & 17.249 & 3.364 .297 & 3.347 .048 \\
Bisnis dan Manajemen & 348.954 & 119.255 & -229.699 \\
Pariwisata & 82.171 & 707.600 & 625.429 \\
Seni dan Industri Kreatif & 12.017 & 88.133 & 76.116 \\
\hline Total & $\mathbf{1 . 2 9 6 . 2 4 6}$ & $\mathbf{5 . 7 5 9 . 7 8 7}$ & $\mathbf{4 . 4 6 3 . 5 4 1}$ \\
\hline
\end{tabular}

Sumber: Dit.PSMK, 2017: 8

Panja Pendidikan Vokasi Komisi X DPR RI (2020) mencermati bahwa rata-rata hanya $40 \%$ lulusan vokasi yang terserap di pasar kerja, menyebabkan 11,2\% lulusan SMK tergolong pengangguran terbuka. Rendahnya keterserapan ini disebabkan: (1) Adanya kesenjangan (gap) antara SMK dengan DUDI; serta (2) Perbedaan penilaian Standar Kompetensi Lulusan (SKL) dan Standar Kompetensi Kerja Nasional Indonesia (SKKNI). Perbedaan penilaian mengakibatkan kualitas Iulusan SMK tidak sama dengan kebutuhan DUDI yang berdasarkan SKKNI. Dengan kata lain, DUDI tidak dapat langsung memanfaatkan lulusan SMK karena secara umum mereka tidak cukup memiliki keterampilan yang dibutuhkan DUDI (Panja Pendidikan Vokasi Komisi X, 2020: 22).

Sementara itu, Kemendikbud menduga masih sedikitnya bekal kemampuan teknis dan nonteknis lulusan SMK menjadi sebab kurang diminati DUDI. Oleh karena itu, Kemendikbud berharap dengan penambahan masa pendidikan dapat memberikan bekal siswa untuk terjun ke DUDI. Sayang, kajian mengenai program pendidikan SMK empat tahun belum menjadi sorotan dunia akademisi. Belum ada penelitian yang menunjukkan efektivitas penambahan masa pendidikan terhadap kebekerjaan lulusan SMK. 


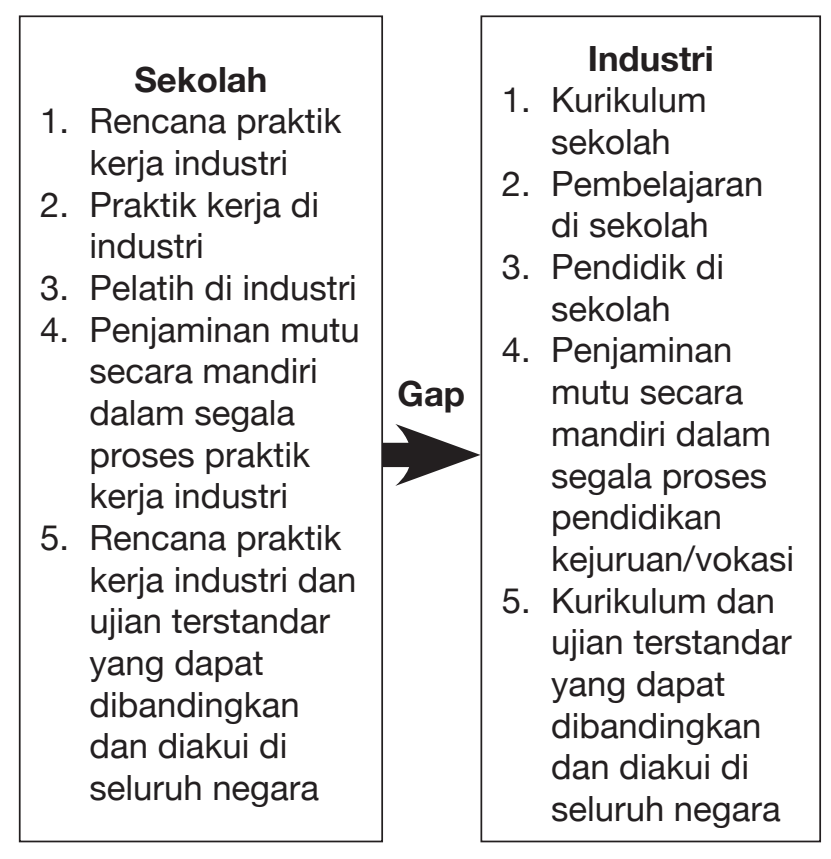

Bagan 1.

Kesenjangan antara SMK dan DUDI

Sumber: Panja Pendidikan Vokasi Komisi X, 2020: 22

Sebaliknya, wacana ini dapat menimbulkan permasalahan baru. Jajak pendapat yang diselenggarakan media elektronik Kumparan (2020b) menemukan $55,25 \%$ dari 809 pembaca memberikan respons setuju dengan perubahan masa pendidikan SMK menjadi empat tahun, sementara $44,75 \%$ sisanya tidak setuju. Berangkat dari masalah tersebut, kajian ini ingin menganalisis permasalahan dan tantangan yang mungkin akan muncul dengan kebijakan SMK empat tahun. Diharapkan kajian ini dapat menjadi masukan dalam perumusan kebijakan pendidikan SMK yang akan datang.

Data yang digunakan dalam kajian ini adalah data sekunder yang berasal dari komen pembaca terhadap berita media elektronik. Untuk menganalisis respons pembaca di atas digunakan teknik analisis konten kuantitatif. Analisis konten sangat bermanfaat untuk mendapatkan gambaran mengenai fenomena sosial. Teknik ini digunakan untuk menganalisis isi komunikasi secara sistematik, objektif, dan kuantitatif (Kriyantono, 2014: 50). Teknik analisis konten kuantitatif yang digunakan dalam penelitian ini dilakukan dengan mengembangkan sistem klasifikasi untuk menganalisis fitur utama sumber media dan kemudian menghitung berapa kali fitur ini muncul dalam teks tertentu. Untuk itu, langkah-langkah yang dilakukan (Slapin, 2018):

1) Memilih teks untuk diperiksa. Peneliti mengumpulkan komen dari media elektronik kumparan.com yang mengunggah berita berjudul "Kemendikbud Akan Ubah Masa Studi SMK Jadi 4 Tahun" dengan url: https://kumparan.com/millennial/ kemendikbud-akan-ubah-masa-studismk-jadi-4-tahun-1 tahxQOTmpT pada tanggal 11 Juni 2020. Berita ini mendapatkan 152 respons dari tanggal 11 s.d. 15 Juni 2020. Meskipun berita mengenai wacana perubahan program ini juga diberitakan di media elektronik lain, namun artikel lain yang senada tidak mendapatkan respons sebanyak ini. Untuk menandai pemilik komen, peneliti memberikan inisial nama pembaca Kumparan beserta tanggal komennya yang disajikan dalam Lampiran.

2) Menentukan unit analisis. Unit analisis yang digunakan adalah kata yang sering muncul terkait dengan pemberitaan wacana SMK 4 tahun. Untuk menjaga kualitas data, peneliti tidak mengubah redaksional komen yang diambil untuk penelitian ini. Peneliti menyisir komen yang memiliki substansi terkait dengan wacana kebijakan perpanjangan masa pendidikan SMK dari tiga tahun menjadi empat tahun sehingga peneliti mendapat gambaran isu-isu yang penting dipertimbangkan sebelum kebijakan diambil. Dari 152 komen, peneliti memilih 56 yang berkaitan dengan substansi penambahan masa pendidikan SMK. Komen yang dikumpulkan disaring dan dikelompokkan dalam 7 tema (lihat Tabel 2). 
Tabel 2.

Komen Pembaca mengenai Wacana Perubahan Program SMK

\begin{tabular}{|c|c|c|}
\hline Isu & Kata Kunci & Contoh Komen \\
\hline \multirow[t]{3}{*}{ Kebekerjaan } & \multirow{3}{*}{$\begin{array}{l}\text { Pengangguran, } \\
\text { kerja susah, } \\
\text { langsung kerja }\end{array}$} & Percuma 4 tahun di smk tpi ujung 2 ny jdi pengangguran... \\
\hline & & sisi buruknya makin banyak aja lulusan S1 nganggur.. \\
\hline & & $\begin{array}{l}\text { Ya ampun... Sekolah empat tahun di smk?,jikalau sekolah lama-lama gitu dan } \\
\text { ada kepastian lulur bisa langsung kerja gak apa2lah... } 5 \text { tahun juga boleh... }\end{array}$ \\
\hline \multirow[t]{2}{*}{$\begin{array}{l}\text { Kualitas } \\
\text { pembelajaran }\end{array}$} & \multirow[t]{2}{*}{ Guru } & $\begin{array}{l}\text { Kalau cuma menambah waktu belajar tanpa perbaikan kwalitas guru dan } \\
\text { peralatan praktikum percuma saja }\end{array}$ \\
\hline & & Kunci paling utama adalah pada tenaga pendidik dan sistem kurikulumnya. \\
\hline \multirow[t]{2}{*}{$\begin{array}{l}\text { Peningkatan } \\
\text { kompetensi }\end{array}$} & \multirow[t]{2}{*}{$\begin{array}{l}\text { Kompetensi, } \\
\text { pelatihan, } \\
\text { praktik kerja } \\
\text { lapangan (PKL) }\end{array}$} & $\begin{array}{l}\text { Saya slaku lulusan Smk stuju slama bertujuan meningkatkan kompentensi } \\
\text { keahlian siswa itu bagus saya berharap ada kurikulum sebelum magang smk } \\
\text { memiliki kerjasama pelatihan dgn industri2 terkait jadi siswa dpat pengetahuan } \\
\text { dan ketrampilan yg nyata dan dpat cepat beradaptasi dgn dunia industri ... }\end{array}$ \\
\hline & & $\begin{array}{l}\text { bagus dong } \\
\text { bisa pkl } 2 \text { kali }\end{array}$ \\
\hline Kualifikasi & $\mathrm{D}-1$ & $\begin{array}{l}\text { Klo memang sekolah } 4 \text { tahun setingkat D1 tolong begitu lulus SMK beri gelar } \\
\text { D1 yaitu A. P }\end{array}$ \\
\hline \multirow{2}{*}{$\begin{array}{l}\text { Lebih } \\
\text { memilih } \\
\text { sekolah } \\
\text { menengah } \\
\text { atas (SMA) }\end{array}$} & \multirow[t]{2}{*}{ Mending SMA } & klo tau Bkl 4taun mending sma saja:( \\
\hline & & $\begin{array}{l}\text { Klw smk di buat } 4 \text { tahun SMA juga dong pasti klw kayal gitu banyak yang } \\
\text { akan ke sma bukan ke smk }\end{array}$ \\
\hline \multirow[t]{2}{*}{ Pembiayaan } & \multirow[t]{2}{*}{$\begin{array}{l}\text { Biaya sekolah, } \\
\text { mahal, bayar }\end{array}$} & $\begin{array}{l}\text { Sangat berat dengan biaya sekolah, sangat berat nanti dpt krj gaji kecil pas } \\
\text { pasan...kalau pengannguran, } 3 \text { th sudah lama , tambah lagi kuliah , dan biaya } \\
\text { nya }\end{array}$ \\
\hline & & Kasian yang pembayaran mahal pakk mereka pasti akan sangat keberatan \\
\hline \multirow[t]{2}{*}{ Usia } & \multirow[t]{2}{*}{ Tua } & apa apan Kga kga 4 tahun lagi tua di sekolah gua kalo bgtu \\
\hline & & $\begin{array}{l}\text { Tua di bangku sekolah pak kemendikbud.. Ampun dah biaya sekolah makin } \\
\text { bengkak }\end{array}$ \\
\hline
\end{tabular}

Sumber: kumparan.com, 11 s.d. 15 Juni 2020

3) Mengembangkan matriks. Dari tujuh tema yang disaring, peneliti melakukan sintesis lanjutan dan menggambarkan keterkaitan antar-tema menjadi seperti diperlihatkan pada Bagan 2.

Data tersebut dilengkapi dengan hasil penelitian Pusat Penelitian Badan Keahlian DPR RI atas permintaan Alat Kelengkapan Dewan (AKD) berjudul "Evaluasi Strategi Revitalisasi Sekolah Menengah Kejuruan di Provinsi DIY" yang dilakukan di Yogyakarta pada tanggal 2 s.d. 8 Maret 2020. Pemilihan Provinsi Daerah Istimewa Yogyakarta (DIY) juga dapat menjadi representasi optimisme pendidikan kejuruan, karena provinsi ini menempati

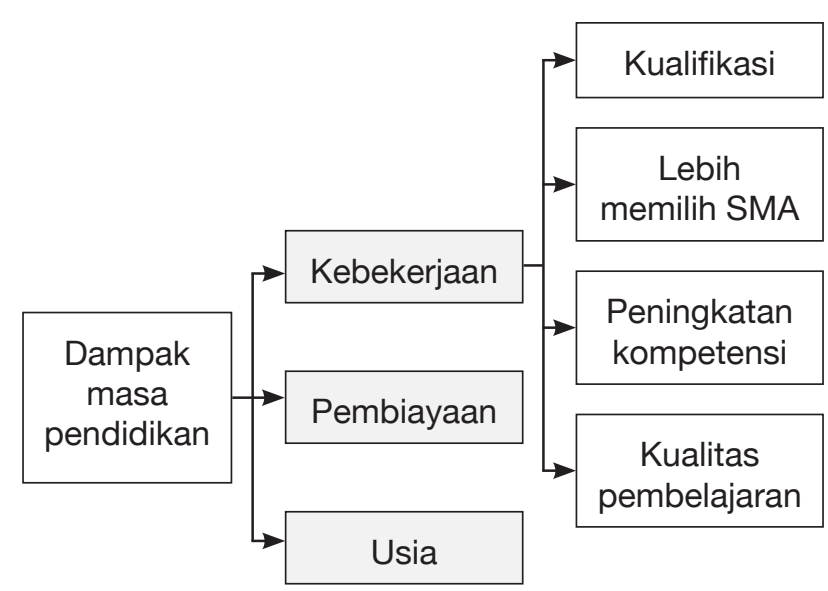

Bagan 2.

Keterkaitan antar-Tema dari Komen Pembaca

Sumber: Disarikan dari kumparan.com, 11 s.d. 15 Juni 2020 
urutan teratas keterserapan lulusan SMK di Indonesia. Dengan kata lain, Provinsi DIY dapat dikatakan merupakan yang terdepan dalam pengembangan pendidikan kejuruan. Data yang digunakan dari penelitian tersebut adalah hasil wawancara yang terkait dengan masa pendidikan SMK. Dalam penelitian tersebut, tim penelitian mewawancarai Dinas Pendidikan, Pemuda, dan Olahraga Provinsi DIY (Dispora Prov. DIY), Dinas Ketenagakerjaan dan Transmigrasi (Disnakertrans Prov. DIY), Kamar Dagang dan Industri Provinsi DIY (KADIN Prov. DIY), dan SMK Negeri 5 Yogyakarta.

Perpaduan kedua data tersebut membantu peneliti untuk mendapatkan gambaran yang lebih kaya mengenai wacana SMK 4 tahun karena berasal dari siswa SMK dan pemerintah sebagai penyelenggara pendidikan kejuruan.

\section{Sikap terhadap Kebijakan Pendidikan}

Studi sikap merupakan salah satu konsep psikologi menarik karena memengaruhi perilaku individu. Pakar behavioris Allport (1935) menjelaskan sikap sebagai keadaan mental atau saraf kesiapan, yang diorganisir melalui pengalaman, memberikan pengaruh direktif atau dinamis pada respons individu terhadap semua objek dan situasi yang terkait. Sementara itu Fishbein dan Ajzen (2005) menjelaskan sikap sebagai seperangkat konstruk yang memengaruhi perilaku. Meskipun begitu, sikap tidak selalu ditampilkan dalam perilaku

Sikap tidak dibentuk dalam sekejap. Banyak sikap terbentuk pada masa awal hidup, tapi juga dapat dipelajari ketika bertemu hal baru, juga dapat berubah sebagai konsekuensi pengalaman, informasi baru maupun pengaruh sosial (Albarracín, Sunderrajan, Lohman, Chan, \& Jiang, 2018). Setidaknya ada empat proses pembentukan sikap yang dijelaskan Albarracín, Sunderrajan, Lohman, Chan, dan Jiang (2018), yaitu melalui:
1) Pengalaman langsung. Pengalaman langsung memengaruhi kemungkinan suatu sikap dapat ditimbulkan ketika berhadapan lagi dengan objek yang sama.

2) Keterpaparan, merupakan fenomena ketika sikap terhadap suatu stimulus menjadi makin disukai seiring meningkatnya frekuensi eksposur terhadap stimulus tersebut.

3) Pengkondisian evaluatif, proses yang mirip dengan teori classical conditioning milik Pavlov, yang muncul ketika stimulus yang terkondisikan secara konsisten dihadirkan di hadapan stimulus yang tidak dikondisikan.

4) Proses yang dipicu oleh komunikasi persuasif dan faktor pengaruh modelmodel persuasi. Sikap terbentuk dan sering berubah mengikuti penerimaan informasi yang disampaikan dalam komunikasi persuasif. Kita menghadapi komunikasi persuasif setiap hari, misalnya ketika teman merekomendasikan film terbaru atau permintaan donasi kemanusiaan di mal.

Sikap berwujud dalam tiga komponen (Jain, 2014: 6-7): pertama, komponen emosional (afektif), yaitu bagaimana perasaan individu terhadap objek, orang, kelompok, kegiatan, atau suatu pekerjaan. Komponen ini dapat berupa rasa senang, bersemangat, terpacu, jijik, nyaman, dan sebagainya. Kedua, komponen kognitif, yang meliputi persepsi, pemikiran, dan ingatan. Sikap dilandasi bagaimana orang mempersepsikan suatu informasi dan seberapa besar maknanya bagi diri sendiri. Orang dapat menganggap suatu objek, orang lain, kelompok, kegiatan atau pekerjaan sebagai suatu yang mudah atau sulit, menantang atau gampang, mengancam atau mendukung, menguntungkan atau merugikan orang lain. Ketiga, komponen perilaku, yang mengkombinasikan pemikiran dan perasaan. Jika seseorang 
menganggap suatu tugas menyenangkan (komponen emosional) dan berguna (komponen kognitif), kemungkinan ia akan melaksanakan tugas dengan cara yang positif (komponen perilaku). Jika diberikan hierarki, maka sikap dapat dijabarkan dalam beberapa tingkatan: (1) menerima stimulus; (2) memberi tanggapan; (3) menghargai; (4) bertanggung jawab atas pilihan yang diambil (Nurmala et al., 2018: 45).

Sikap dapat memberikan motif dan fungsi yang berbeda bagi individu. Menurut Katz (1960, dalam Albarracin et al., 2018), sikap memiliki empat fungsi, yaitu: (1) fungsi pengetahuan, yang menunjukkan sikap dapat mengatur informasi mengenai lingkungan; (2) fungsi utilitarian mencerminkan penghargaan dan hukuman yang diasosiasikan dengan objek sikap; (3) fungsi pertahanan ego yang menunjukkan bahwa sikap merupakan bentuk proteksi diri individu; dan (4) fungsi ekspresi nilai yang mengekspresikan konsep diri individu. Ditambahkan pula oleh Smith et al. (1956, dalam Albarracin et al., 2018) fungsi penyesuaian yang menunjukkan sikap dapat membantu untuk mengidentifikasi dengan orang yang kita sukai dan deidentifikasi dengan orang yang tidak kita sukai.

\section{Pengembangan Pendidikan SMK}

\section{Kebekerjaan}

Ketika membahas mengenai pendidikan kejuruan, isu yang paling sering muncul adalah kemudahan mendapatkan kerja, atau yang dalam tulisan ini disebut kebekerjaan. Meskipun pendidikan kejuruan telah dimulai sejak sebelum masa kemerdekaan, pengembangannya tidak semaju pendidikan umum, yang menyebabkan terjadinya persoalan kebekerjaan di dunia pendidikan kejuruan. Ketika mengevaluasi proyek revitalisasi SMK, Asian Development Bank menulis lulusan SMK tidak memiliki keterampilan yang memadai untuk masuk ke DUDI, dan mengakibatkan pengangguran di seluruh penjuru negeri (ADB, 2016: 1). Kondisi ini sesuai dengan kesimpulan Tentama dan Merdiaty (2020: 230) yang menekankan banyak siswa dan lulusan SMK saat ini tidak memiliki kemampuan kerja yang meyakinkan dan sesuai, sesuai dengan data BPS tahun 2016.

Masih tingginya angka pengangguran lulusan SMK menunjukkan belum optimalnya perhatian pemerintah terhadap pembangunan sumber daya manusia. Angka pengangguran usia muda merupakan permasalahan yang sulit diabaikan. Pada tahun 2017, jumlah penduduk usia muda (15-24) yang tidak sedang sekolah, bekerja, atau mengikuti pelatihan adalah sebanyak $21,41 \%$, namun komposisi ini naik menjadi $22,84 \%$ di tahun 2018 (BPS, 2018). Pada Februari 2020, TPT untuk SMK menempati posisi tertinggi yaitu sebesar 8,49\% (BPS, 2020: 131).

Tenaga kerja lulusan SMK seharusnya menjadi pilihan industri karena telah dilatih untuk memenuhi kebutuhan praktis industri. Namun, jumlah tenaga kerja lulusan SMK yang diserap tidak sesuai dengan jumlah lulusan SMK. Pada tahun 2018 jumlah lulusan SMK yang terserap di dunia kerja tidak lebih dari $22,2 \%$ (lihat Tabel 3).

Masalah kebekerjaan menjadi
lebih menantang dengan kehadiran era industri 4.0, yang bukan saja membawa (1) tantangan teknologi (terjadinya penggantian tenaga kerja berketerampilan rendah dengan mesin dan rendahnya penguasaan teknologi; (2) mismatch pekerjaan dengan pendidikan, yang menyebabkan rendahnya daya saing tenaga kerja Indonesia dengan tenaga kerja asing; tapi juga (3) masih banyaknya tenaga kerja informal, yang produktivitasnya rendah serta tidak dilindungi jaminan sosial (Kemenkeu, 2019: II2.-15). Dengan kata lain, ada pergeseran kebutuhan kompetensi di dunia kerja yang menuntut dunia pendidikan untuk beradaptasi dengan kebutuhan pasar. 
Tabel 3.

Tenaga Kerja Lulusan SMK, Tahun 2018

\begin{tabular}{|c|c|c|c|}
\hline \multirow{3}{*}{ Provinsi } & \multicolumn{3}{|c|}{ Jumlah Tenaga Kerja } \\
\hline & \multirow[b]{2}{*}{ Total } & \multicolumn{2}{|c|}{ Lulusan SMK } \\
\hline & & Total & $\begin{array}{c}\text { Persentase } \\
(\%)\end{array}$ \\
\hline Papua & 1,8 juta & 73,6 ribu & 4,1 \\
\hline Aceh & 2,2 juta & 100,4 ribu & 4,6 \\
\hline Sulawesi Tenggara & 1,2 juta & 62,5 ribu & 5,2 \\
\hline Maluku Utara & 515,6 ribu & 26,9 ribu & 5,2 \\
\hline Nusa Tenggara Barat & 2,2 juta & 120,6 ribu & 5,6 \\
\hline Nusa Tenggara Timur & 2,4 juta & 140,6 ribu & 5,8 \\
\hline Kalimantan Barat & 2,4 juta & 139,2 ribu & 5,9 \\
\hline Sumatera Selatan & 3,97 juta & 254,4 ribu & 6,4 \\
\hline Sulawesi Barat & 619,4 ribu & 40,8 ribu & 6,6 \\
\hline Sulawesi Tengah & 1,45 juta & 97,8 ribu & 6,7 \\
\hline Jambi & 1,7 juta & 120 ribu & 6,97 \\
\hline Sulawesi Selatan & 3,8 juta & 257 ribu & 6,8 \\
\hline Gorontalo & 555,5 ribu & 38,5 ribu & 6,9 \\
\hline Maluku & 700,1 ribu & 48,6 ribu & 6,9 \\
\hline Kalimantan Tengah & 1,3 juta & 93,5 ribu & 7,2 \\
\hline Kalimantan Selatan & 2,02 juta & 146,1 ribu & 7,2 \\
\hline Papua Barat & 417,5 ribu & 34,6 ribu & 8,3 \\
\hline Bengkulu & 963,5 ribu & 82,4 ribu & 8,6 \\
\hline Lampung & 4,1 juta & 376,4 ribu & 9,3 \\
\hline Riau & 2,9 juta & 296 ribu & 10,2 \\
\hline Sumatera Barat & 2,4 juta & 253,4 ribu & 10,5 \\
\hline Jawa Timur & 20,4 juta & 2,2 juta & 10,7 \\
\hline Kalimantan Utara & 323,4 ribu & 34,7 ribu & 10,7 \\
\hline Jawa Tengah & 17,2 juta & 1,93 juta & 11,2 \\
\hline Kep. Bangka Belitung & 701,4 ribu & 79 ribu & 11,3 \\
\hline Banten & 5,3 juta & 630,9 ribu & 11,8 \\
\hline Sulawesi Utara & 1,1 juta & 129,2 ribu & 11,8 \\
\hline Sumatera Utara & 6,7 juta & 884,7 ribu & 13,1 \\
\hline Jawa Barat & 20,7 juta & 2,8 juta & 13,6 \\
\hline Bali & 2,5 juta & 350,9 ribu & 14,1 \\
\hline Kalimantan Timur & 1,6 juta & 258,6 ribu & 15,98 \\
\hline DKI Jakarta & 4,7 juta & 906,6 ribu & 19,2 \\
\hline Kepulauan Riau & 901 ribu & 184,9 ribu & 20,5 \\
\hline DI Yogyakarta & 2,2 juta & 470,2 ribu & 22,2 \\
\hline
\end{tabular}

Sumber: Dit.PSMK, 2019b

Perubahan era ikut memengaruhi permintaan pasar terhadap tenaga kerja terampil. Perhitungan Lembaga Demografi UI di tahun 2018 yang dikutip oleh Dit. PSMK (2019b) menunjukkan dari 17 sektor perekonomian, 5 (dari 17 sektor) yang menyerap tenaga kerja lulusan SMK terbesar adalah sektor perdagangan $(26,32 \%)$, industri pengolahan $(23,0 \%)$, pertanian $(9,10 \%)$, akomodasi makan dan minum $(7,96 \%)$, dan transportasi $(6,23 \%)$.

\section{Spektrum Keahlian dan Proses Pembelajaran}

Berkaca dari perhitungan peluang kebekerjaan di atas, pendidikan kejuruan terus mengalami perbaikan, salah satunya dengan merumuskan spektrum keahlian yang sedang dibutuhkan di pasar tenaga kerja. Perumusan ulang spektrum keahlian SMK sudah beberapa kali dilakukan. Hal ini disesuaikan dengan delapan standar nasional pendidikan SMK yang disusun oleh Badan Standar Nasional Pendidikan (BSNP). Semenjak diinisiasinya revitalisasi SMK, penyusunan pengaturan spektrum keahlian SMK telah dikembangkan sebanyak dua kali. Yang pertama adalah melalui Surat Edaran Direktur Pembinaan SMK Nomor 8275/D5.3/KR/2016 tertanggal 15 November 2016 tentang Spektrum Keahlian Pendidikan Menengah Kejuruan yang memutuskan 142 spektrum keahlian. Kemudian disempurnakan dengan Perdirjen Dikdasmen No. 06/D. D5/KK/2018 yang menetapkan Spektrum Keahlian PMK 2018 sehingga sekarang terdapat 146 kompetensi keahlian SMK. Peraturan ini juga memutuskan 110 kompetensi keahlian dilaksanakan dalam tiga tahun dan 36 kompetensi lainnya dilangsungkan dalam program empat tahun. Akibatnya 480 SMK ditetapkan sebagai pelaksana program 4 tahun (Dit. PSMK, 2018: 114).

Program pendidikan di SMK dirancang untuk mengajarkan dan mengasah keterampilan peserta didik. Berbeda dengan pendidikan menengah lainnya, pendidikan kejuruan memberikan penekanan terhadap pelatihan keterampilan, oleh karena itu kegiatan praktik menjadi vital. Secara umum pelaksanaan praktik di SMK untuk SMK tiga tahun dan SMK empat tahun dijelaskan pada Tabel 4 berikut.

Dalam pengaturan Kemendikbud, praktik di SMK diorganisasikan sebagai berikut (Kemendikbud, 2016: 54):

1) Tahun pertama adalah praktik keterampilan kejuruan yang merupakan bagian dari rencana pembelajaran tingkat dasar yang dilaksanakan di ruang praktik sekolah.

2) Tahun kedua adalah praktik kompetensi kerja untuk 6 bulan pertama dan 
Tabel 4.

Pelaksanaan Praktik Dual System di SMK

\begin{tabular}{|c|c|c|c|c|}
\hline Kelas & \multicolumn{2}{|c|}{ Program Tiga Tahun } & \multicolumn{2}{|c|}{ Program Empat Tahun } \\
\hline $\mathbf{x}$ & \multicolumn{2}{|c|}{ Praktik keterampilan kejuruan } & \multicolumn{2}{|c|}{ Praktik keterampilan kejuruan } \\
\hline $\mathbf{X I}$ & $\begin{array}{l}\text { Praktik kompetensi } \\
\text { kerja }\end{array}$ & $\begin{array}{l}\text { Praktik realisasi } \\
\text { produk di teaching } \\
\text { factory }\end{array}$ & \multicolumn{2}{|c|}{ Praktik kompetensi kerja } \\
\hline XII & $\begin{array}{l}\text { Praktik magang } \\
\text { industri }\end{array}$ & $\begin{array}{l}\text { Transisi jenjang karier, } \\
\text { UN, dan sertifikasi }\end{array}$ & $\begin{array}{l}\text { Praktik magang } \\
\text { industri }\end{array}$ & $\begin{array}{c}\text { Praktik realisasi } \\
\text { produk di teaching } \\
\text { factory }\end{array}$ \\
\hline XIII & & & $\begin{array}{l}\text { Praktik magang } \\
\text { industri }\end{array}$ & $\begin{array}{c}\text { Transisi jenjang karier, } \\
\text { UN, dan sertifikasi }\end{array}$ \\
\hline Waktu & 6 bulan & 6 bulan & 6 bulan & 6 bulan \\
\hline
\end{tabular}

Sumber: Kemendikbud, 2016: 54

praktik realisasi produk di teaching factory dasar yang dilaksanakan di ruang praktik sekolah. Tahapan ini merupakan tahap spesialisasi pertama, tetapi spesialisasi ini masih bersifat luas. Spesialisasi ini berorientasi pada kemampuan khusus yang esensial pada suatu ruang lingkup kelompok kejuruan kecil. Adapun pada SMK empat tahun, tahun kedua difokuskan pada praktik kompetensi kerja.

3) Tahun ketiga adalah praktik magang industri pada 6 bulan pertama dan diikuti dengan transisi jenjang karier, pelaksanaan UN, dan sertifikasi. Praktik magang industri dilakukan di DUDI difokuskan pada spesialisasi keterampilan khusus dari suatu bidang kerja dan yang secara khusus diperlukan oleh tempat kerja. Adapun untuk SMK empat tahun dilakukan praktik magang industri tahap ke-1 pada 6 bulan pertama, kemudian dilanjutkan dengan praktik realisasi produk di teaching factory dasar yang dilaksanakan di ruang praktik sekolah.

4) Tahun keempat adalah praktik magang industri tahap ke-2 pada 6 bulan pertama dan diikuti dengan transisi jenjang karier, pelaksanaan UN, dan sertifikasi diklat difokuskan pada spesialisasi keterampilan khusus dari suatu bidang kerja dan yang secara khusus diperlukan oleh tempat kerja.

\section{Pembiayaan Pendidikan}

Proses pembelajaran yang berlangsung di SMK tentu memiliki konsekuensi finansial. Pembiayaan pendidikan kejuruan dapat dibagi menjadi biaya langsung, yang meliputi honor murid magang, gaji pelatih, bahan ajar, peralatan, infrastruktur gedung, dan sebagainya; serta biaya tidak langsung seperti pengeluaran/subsidi pajak, tapi juga biaya kesempatan yang diberikan kepada murid magang (yang menyebabkan rendahnya produktivitas) dan biaya drop out. Dibandingkan dengan pendidikan umum, biaya pendidikan kejuruan memang jauh lebih mahal (Hoeckel, 2008: 4). Untuk itu, idealnya pendidikan kejuruan harus diselenggarakan dengan kerja sama dari berbagai pemangku kepentingan. Dalam laporannya untuk OECD, Hoeckel menguraikan jenis biaya yang harus ditanggung oleh setiap pihak dalam penyelenggaraan pendidikan kejuruan (lihat Tabel 5).

\section{Usia dan Kematangan Emosional}

Hal lain yang tidak dapat dilepaskan dalam proses pendidikan adalah membantu seseorang mengubah sikap dan perilaku. Murid yang belajar di 
Tabel 5.

Ragam Biaya Pemangku Kepentingan Pendidikan Kejuruan

\begin{tabular}{|c|c|c|}
\hline Stakeholders & Pendidikan Kejuruan & Pelatihan Kerja \\
\hline \multirow[t]{2}{*}{ Individu } & Biaya pendidikan & Menerima gaji rendah \\
\hline & Biaya bahan/alat & $\begin{array}{l}\text { Biaya kesempatan (tidak memperoleh pendapatan sebagai } \\
\text { pekerja tidak terampil) }\end{array}$ \\
\hline \multirow[t]{3}{*}{ Pemberi kerja } & Pembayaran cuti & Membayar gaji lebih tinggi daripada produktivitas \\
\hline & $\begin{array}{l}\text { Dukungan finansial } \\
\text { bagi karyawan }\end{array}$ & $\begin{array}{l}\text { Adanya kesalahan dari tenaga pelatihan yang tidak } \\
\text { berpengalaman, terbuangnya sumber daya dan waktu pekerja } \\
\text { yang berpengalaman }\end{array}$ \\
\hline & & Biaya pelatihan (material, seragam, gaji pengajar, administrasi) \\
\hline \multirow[t]{2}{*}{ Negara } & $\begin{array}{l}\text { Pembiayaan instansi } \\
\text { pendidikan }\end{array}$ & Subsidi bagi lembaga pelatihan \\
\hline & $\begin{array}{l}\text { Beasiswa, voucher, } \\
\text { hibah, dan pinjaman }\end{array}$ & $\begin{array}{l}\text { Keringanan finansial bagi pemberi kerja (insentif/tunjangan } \\
\text { pajak) }\end{array}$ \\
\hline
\end{tabular}

institusi pendidikan tidak hanya dibekali keterampilan teknis untuk mengerjakan tugas di dunia kerja, tapi juga dilatih untuk kematangan mental bekerja. Seiring bertambahnya usia, seseorang akan mengembangkan kematangan. Orang dianggap tidak matang jika performanya di bawah standar orang-orang lain seusianya. Dr. Rekha Rani (2015) menulis salah satu bentuk kematangan seseorang adalah kesiapan untuk membuat pilihan karier sesuai dengan tahap perkembangan. Setiawati dan Endrastuti (2019: 350) menemukan pentingnya kematangan emosional bagi remaja dalam beradaptasi dengan lingkungannya sehingga ia tidak mudah terprovokasi dan menjauh dari pengaruh negatif. Kematangan emosional ini juga membantu mereka untuk dapat berpikir kritis sebelum melakukan sesuatu yang berbahaya bagi dirinya dan orang lain. Tanpa kematangan emosional dan kesejahteraan keseluruhan, sulit bagi remaja untuk berhasil dalam tujuantujuan hidupnya (Joy \& Mathew, 2018: 4). Kematangan emosional pada remaja dapat membantu mengontrol dirinya dan meminimalisir hal-hal negatif (Setiawati \& Endrastuti, 2019: 350).
Menurut C. V. Good (1973, dalam Rani, 2015), karakteristik ketidakmatangan emosional antara lain: (1) Moody dan depresi sepanjang waktu; (2) Menangis, mutung, kehilangan kesabaran dan berteriak karena masalah sepele; (3) Terlambat memenuhi janji atau melalaikan tugas sekolah/tanggung jawab karena hobi; (4) Begadang ketika harus istirahat sehingga terlambat bangun untuk sekolah/ kerja; (5) Malas bangun dan minta izin sakit ketika merasa sedikit lelah, padahal seharusnya bersikap disiplin dan mengutamakan tanggung jawab; (6) Menuntut orang lain mengutamakan diri sendiri; (7) Belanja secara impulsif; (8) Mengabaikan konsekuensi; (9) Tidak dapat menguraikan alasan atas suatu situasi atau masalah dari awal sampai akhir sebelum mengambil keputusan (bertindak sebelum berpikir); (10) Mudah dipengaruhi orang lain (daripada menggunakan pemikiran dan membuat keputusan sendiri); (11) Berkhayal, menghabiskan waktu di dunia fantasi; (12) Bereaksi secara emosional dan ambyar di saat keadaan darurat. Secara umum ketidakmatangan berarti tidak mampu mengumpulkan keberanian dan bertindak dengan pemikiran yang jernih setelah terjadi masalah. 


\section{Sikap Pembaca terhadap Wacana SMK Empat Tahun}

Berkembangnya wacana perubahan program pendidikan SMK dari tiga tahun menjadi empat tahun merupakan pemicu untuk mempelajari perlu tidaknya perubahan ini. Meskipun Dit. PSMK menyatakan bahwa tidak semua SMK akan diperpanjang waktu pendidikannya, wacana ini telah menuai berbagai respons yang patut dipertimbangkan sebelum mengambil kebijakan perubahan program pendidikan SMK. Dari data yang dikumpulkan, peneliti mengelompokkan menjadi tiga isu utama.

Pertama, kebekerjaan. Tujuan utama siswa masuk ke SMK adalah agar cepat mendapatkan pekerjaan. Pendidikan kejuruan dianggap dapat mencetak tenaga kerja siap pakai. Akan tetapi, Iulusan SMK tidak mudah untuk mendapatkan pekerjaan. Beberapa pembaca mengeluhkan sulit dan ketidakpastian pekerjaan bagi lulusan SMK. Tidak adanya kepastian kebekerjaan lulusan SMK ini disebabkan karena sekolah tidak menjalin kerja sama dengan DUDI. Bagi sekolah yang memiliki MoU dengan mitra usaha, bukan saja dapat mengirimkan siswanya untuk melakukan praktik kerja industri, tapi membuka peluang perekrutan jika siswa yang $\mathrm{PKL}$ dianggap sesuai dengan standar industri seperti disampaikan dalam wawancara di SMK 5 Prov. DIY. SMK 5 Prov. DIY yang termasuk sekolah terbaik, melakukan sendiri pemilihan mitra DUDI yang juga berdasarkan usulan siswa.

Namun ternyata, kerja sama antara SMK di provinsi DIY dan DUDI hanya dilakukan oleh beberapa sekolah. Sekolah dipaksa berinisiatif untuk mengundang dan mengajak DUDI dalam proses pembelajarannya. Kepala sekolah yang berwawasan wirausaha akan cepat dalam menangkap kesempatan kerja sama, misalnya SMK Negeri 5 Yogyakarta yang memiliki daftar mitra praktik kerja bagi siswanya, atau kelas-kelas teknologi di SMK Muhammadiyah yang didapat dari Samsung, juga kerja sama ekspor komputer dengan perusahaan Korea di SMK Kalasan. Sementara, peran pemerintah provinsi, terutama Dinas Pendidikan, Pemuda, dan Olahraga (Dispora) dalam mengawinmassalkan SMK dengan DUDI masih lemah.

Dispora Prov. DIY mengakui belum ada program khusus untuk mengawinkan SMK dengan DUDI. Melihat masih kurangnya perhatian pemerintah provinsi terhadap permasalahan ketenagakerjaan lulusan SMK ini, muncul inisiatif dari DUDI yang menjadi anggota KADIN Prov. DIY dan Disnaker Prov. DIY dengan membantu mempertemukan sekolah-sekolah yang belum memiliki mitra dengan perusahaan yang dapat menerima PKL. KADIN Prov. DIY telah melatih instruktur pemagangan yang akan mengarahkan siswa yang melakukan PKL di perusahaan. Dengan begitu, siswa mendapatkan manfaat optimal dalam kegiatan PKL-nya.

Pentingnya mengikuti tren pasar juga perlu menjadi pertimbangan. Dalam komennya, salah seorang pembaca mengeluhkan banyaknya jumlah SMK, namun hanya sedikit lulusannya yang diserap pasar. Hal ini disebabkan pembukaan bidang keahlian tidak disesuaikan dengan permintaan pasar. Ada beberapa bidang keahlian favorit karena dianggap mudah mendapatkan pekerjaan, seperti bidang bisnis manajemen. Oleh karena itu, pemerintah mendorong pembelajaran kewirausahaan untuk mengubah pola pikir pekerja menjadi pelaku usaha. Hal ini yang dilakukan SMK 5 dengan membuka bidang-bidang keahlian digital yang memberikan wawasan kepada siswa untuk dapat memasarkan produknya secara daring. Dengan begitu, meskipun mereka tidak bekerja di pabrik atau perusahaan besar, mereka dapat berkarya dan menghasilkan peluang usaha sendiri. $\mathrm{Hal}$ ini sangat membantu bagi siswa yang mengikuti jurusan kerajinan/kriya. 
Isu kebekerjaan ini terkait dengan tiga sub-isu, yaitu masalah kompetensi, PKL, dan kualitas pembelajaran. Jika diterapkan empat tahun, maka lulusan SMK seharusnya mendapatkan kualifikasi dan kompetensi yang lebih tinggi dari sekarang, karena mereka memiliki waktu lebih panjang untuk melakukan PKL. Dengan pendalaman praktik ini diharapkan lulusan SMK juga lebih mahir dalam bidangnya. Menurut Dispora Prov. DIY, jika kualitas pembelajaran tidak diubah dan diakselerasi dengan perkembangan industri, maka pendidikan kejuruan hanya akan mengulangi sejarah lama: membina siswa dengan fokus pada teori, namun lemah dalam hal keterampilan.

Pembaca lain juga menyinggung lamanya masa pendidikan SMK akan menyebabkan daya tarik SMK semakin menurun dan siswa akan memilih untuk masuk SMA. Di satu sisi, ijazah SMK seharusnya bernilai lebih dibandingkan SMA yang hanya 3 tahun karena dianggap berpengalaman. Namun, menurut Dispora Prov. DIY, jumlah SMK yang lebih banyak dibandingkan dengan SMA menyebabkan tidak semua peminat SMA dapat tertampung. Kondisi ini patut menjadi alasan untuk mempertanyakan kebijakan pemerintah yang memperbanyak jumlah SMK dengan rasio 70:30 dibandingkan SMA. Dengan rendahnya daya jual lulusan SMK, kebijakan ini malah menjadi senjata makan tuan, karena hanya akan menghasilkan penambahan angka pengangguran.

Kedua, pembiayaan. Pembaca mengeluhkan peningkatan pembiayaan jika masa pendidikan ditambah satu tahun. Pembelajaran di SMK membutuhkan biaya bukan hanya untuk pertemuan di kelas, tapi terlebih pada kegiatan praktik. Untuk pembelajaran empat tahun siswa dihadapkan pada tiga praktik: praktik kompetensi kerja, praktik magang industri dan praktik realisasi teaching factory. Padahal, pembiayaan praktik tidak murah. Seperti yang pernah ditulis Djojonegoro
(1998, dalam Damarjati, 2019), pendidikan kejuruan memerlukan fasilitas yang mutakhir untuk praktik.

Harus diakui bahwa politik anggaran pendidikan nasional belum berpihak kepada kelancaran peningkatan mutu dan kualitas pendidikan nasional (Khurniawan \& Majid, 2019). Pembiayaan praktik di SMK negeri yang dirancang dalam postur anggaran Kemendikbud terbukti tidak memadai. Pertumbuhan jumlah SMK tidak diiringi pertumbuhan alokasi anggaran untuk SMK yang proporsional (Khurniawan \& Majid, 2019: 2). Tentu tidak adil ketika Pemerintah mendorong pertumbuhan SMK, namun tidak memiliki cukup anggaran untuk mengembangkan pendidikan kejuruan ini. Akibatnya sekolah harus mencari sumber dana lain. Dalam Peraturan Pemerintah Nomor 48 Tahun 2008 tentang Pendanaan Pendidikan disebutkan pendanaan pendidikan yang diselenggarakan pemerintah bersumber dari pemerintah, yang ditambah dari masyarakat, bantuan pihak asing yang tidak mengikat, dan/atau sumber lain yang sah.

Sementara itu, pendidikan yang diselenggarakan masyarakat didanai oleh pemilik/yayasan pendidikan dengan ditambah dana yang berasal dari yayasan, orang tua/wali peserta didik, masyarakat di luar orang tua/wali, bantuan pihak asing yang tidak mengikat, dan/atau sumber lain yang sah. Bagi siswa, pembiayaan pendidikan ini ditagihkan dalam bentuk SPP, namun komponennya sebenarnya meliputi pembiayaan standar isi, standar proses, standar penilaian, standar kompetensi lulusan, standar pendidik dan tenaga kependidikan, standar sarpras, standar pengelolaan dan standar pembiayaan (Khurniawan \& Majid, 2019: 2). Sebagai contoh, dalam kajian UNS (Universitas Sebelas Maret) pada tahun 2018, seorang siswa pada bidang keahlian bisnis manajemen membutuhkan biaya Rp5.667.000 per tahun atau Rp472.250 per bulannya. Nilai ini bisa berbeda di 
bidang keahlian lain karena kebutuhan pemenuhan peralatan praktik. Hasil survei Tim Dit.PSMK pada bulan Januari sampai bulan Maret 2019 menyimpulkan peralatan praktik bidang keahlian teknologi dan rekayasa paling mahal, sementara yang bidang bisnis manajemen paling murah. Tabel di bawah dapat memberikan gambaran besarnya kebutuhan biaya untuk peralatan praktik.

Tabel 5.

Satuan Biaya Peralatan Praktik per Ruang Praktik Siswa (RPS) dari Rata-Rata Biaya Peralatan Praktik Program Keahlian

\begin{tabular}{lc}
\hline \multicolumn{1}{c}{ Bidang Keahlian } & $\begin{array}{c}\text { Satuan Biaya } \\
\text { Pemenuhan } \\
\text { Peralatan } \\
\text { Praktik } \\
\text { Lengkap } \\
\text { (Rupiah) }\end{array}$ \\
\hline Teknologi dan Rekayasa & 5.715 .517 .000 \\
Energi dan Pertambangan & 5.083 .000 .000 \\
Teknologi Informasi \& Komunikasi & 1.983 .000 .000 \\
Kesehatan dan Pekerjaan Sosial & 1.500 .000 .000 \\
Agribisnis dan Agroteknologi & 2.840 .000 .000 \\
Kemaritiman & 3.790 .000 .000 \\
Bisnis Manajemen & 875.000 .000 \\
Pariwisata & 1.588 .000 .000 \\
Seni dan Industri Kreatif & 1.978 .000 .000 \\
\hline
\end{tabular}

Sumber: Khurniawan \& Majid, 2019: 23

Menurut risetnya, Khurniawan dan Majid (2019) menemukan SMK mengandalkan dana BOS yang tidak cukup untuk memenuhi standar pembiayaan operasional. Akibatnya, pembiayaan menjadi tanggungan siswa. Hal ini menjadi tambahan beban bagi siswa, apalagi banyak siswa SMK yang berasal dari kondisi keluarga ekonomi lemah (Dharmaningtyas \& Subkhan, 2012: 269).

Ketiga, usia calon tenaga kerja. Ini adalah sebuah isu yang jarang muncul, namun ternyata menjadi perhatian pembaca. Dengan menambah satu tahun masa pendidikan, rata-rata lulusan SMK akan menjadi 19-20 tahun. Di satu sisi, bertambahnya satu tahun menyebabkan lulusan kehilangan kesempatan untuk mulai bekerja lebih awal. Komen pembaca selaras dengan hasil wawancara Dispora Prov. DIY (2020) yang menyatakan motivasi orang tua memasukkan anaknya ke SMK adalah agar dapat cepat bekerja. Di sini kita lihat bahwa pembaca lebih fokus pada waktu yang diinvestasikan untuk mendapatkan pekerjaan. Semakin lama masa belajar, maka lulusan SMK akan kehilangan waktu untuk mendapatkan penghasilan dengan bekerja.

Di sisi lain, Kadin Prov. DIY (2020) lebih menyoroti aspek hukumnya. Jika lulusan SMK berusia 18 tahun langsung bekerja maka dapat bertentangan dengan undang-undang ketenagakerjaan, karena usia 18 tahun masih digolongkan anakanak, sedangkan Indonesia melarang praktik pekerja anak. Selain itu, menurut Dispora Prov. DIY, konteks anak-anak di sini sangat erat dengan kesiapan mereka memasuki dunia kerja secara fisik dan mental. Sebab lulusan yang memasuki dunia kerja memiliki tantangan dan tanggung jawab yang berbeda dengan siswa. Di Provinsi DIY sendiri, Dispora memandang proses pembelajaran empat tahun sangat membantu mendewasakan siswa, sebagaimana yang dilakukan oleh STM Pembangunan dan SMK 2 Depok yang dianggap berkualitas tinggi.

Lulusan SMK merupakan angkatan kerja yang paling muda yang dihasilkan pendidikan formal. Bekerja di usia dini memberikan dampak psikologis tertentu bagi individu. Di satu sisi, pekerja muda dipaksa memiliki kematangan emosional untuk mengikuti aturan-aturan di dunia kerja. Oleh karena itu, masa belajar di SMK harus dapat mempersiapkan murid mengembangkan kematangan emosional, sebagaimana yang disinggung Setiawati dan Endrastuti (2019) serta Rekha Rani (2015).

\section{Pentingnya Peningkatan Peran Pemerintah Provinsi}

SMK bertujuan mempersiapkan lulusan siap kerja, oleh karena itu orang tua berharap anaknya disekolahkan ke 
SMK agar segera mendapatkan pekerjaan. Kunci dari kebekerjaan adalah sesuainya kebutuhan dengan suplai. Dengan kata lain pendidikan kejuruan harus mencetak lulusan yang benar-benar dibutuhkan DUDI. Secara konkret, hal ini hanya bisa diraih jika sekolah dan DUDI bekerja sama untuk melakukan pembelajaran yang akan membentuk tenaga terampil sesuai keinginan. Untuk melaksanakan hal tersebut DUDI harus dilibatkan dalam penyusunan kurikulum di sekolah. Selain itu, DUDI juga harus menyumbang tenaga dalam menghadirkan guru tamu dan memberikan kesempatan bagi guru SMK untuk magang.

Hal ini sesuai dengan rekomendasi Panja Pendidikan Vokasi Komisi X untuk melibatkan industri dalam menentukan arah pengembangan sekolah dari hulu ke hilir, yaitu: (1) DUDI ikut menentukan isi kurikulum pendidikan kejuruan; (2) Praktik kerja di DUDI selaras dengan pembelajaran di sekolah; (3) Pendidik dan pelatih yang berkualitas baik di DUDI dan di sekolah; (4) Penjaminan mutu secara mandiri; dan (5) Kurikulum dan ujian terstandar yang dapat dibandingkan dan diakui seluruh negara.

Perubahan program pendidikan dari tiga tahun menjadi empat tahun merupakan langkah yang patut didukung untuk meningkatkan keterampilan Iulusan SMK. Diharapkan dengan semakin panjangnya masa praktik, maka level kompetensi yang dicapai pun sesuai dengan kebutuhan DUDI. Konsep link and match antara dunia pendidikan dan DUDI terus-menerus digaungkan pemerintah, namun di lapangan ternyata minim peran konkret dari pemerintah provinsi sebagai pemegang kewenangan pendidikan kejuruan. Di DIY, malah sekolah yang harus berinisiatif untuk mencari DUDI yang bersedia bekerja sama dengan sekolah baik dalam hal PKL maupun penyaluran lulusan. Bahkan upaya menjembatani lebih banyak dilakukan DUDI melalui KADIN Provinsi DIY dibandingkan Dispora Provinsi DIY.
Reformasi pendidikan yang diusung pemerintah bertujuan menjadikan Indonesia sebagai salah satu negara kejuruan (vokasi) pada tahun 2025, dengan rasio SMA dan SMK berkisar 30:70 sehingga mulai dari kabupaten/kota sampai dengan nasional akan dikuasai oleh sekolah kejuruan (Kamdi, 2017: 12-13). Arah pengembangan pendidikan kejuruan ini menyebabkan pertumbuhan sekolah kejuruan menjadi lepas kendali sehingga ada bidang-bidang keahlian yang terus dibuka karena ada peminat, meskipun minim permintaan pasarnya.

Di Provinsi DIY sendiri tidak ada industri besar namun jumlah SMKnya mencapai 220 sekolah. Lulusan SMK-nya banyak bergelut di industri rumah tangga. Penulis setuju dengan Dharmaningtyas dan Subkhan (2012: 85) yang menyatakan jika lulusan SMK membludak, maka akan terjadi booming tenaga kerja teknis terampil di Indonesia. Hal ini menyebabkan lulusan SMK tidak memiliki daya tawar di pasar kerja sehingga mereka dapat terjebak dalam kontrak kerja murah. Dharmaningtyas dan Subkhan (2012: 85) menyebut ini sebagai fenomena vokasionalisasi pendidikan yang memaksakan pendidikan kejuruan yang bergantung pada industri sehingga mendongkrak pertumbuhan industri yang tidak tepat.

Di sini kita melihat masih lemahnya peran pemerintah daerah dalam mengelola pendidikan kejuruan, terutama dalam memastikan terjalinnya kerja sama antara DUDI dan sekolah. Penguatan fungsi pemerintah daerah menjadi urgen karena tanpa adanya partisipasi aktif dinas pendidikan maka akan terjadi ketimpangan di mana hanya SMK yang memiliki daya inovasi yang dapat menyalurkan lulusannya, sementara SMK yang pasif hanya akan menjadi produsen lulusan yang menumpuk. 


\section{Penutup}

Penambahan program pendidikan menjadi empat tahun berpotensi untuk memberikan lebih banyak waktu bagi siswa SMK untuk mempelajari dan melatih keterampilan dengan kualifikasi yang lebih tinggi dibandingkan dengan hanya tiga tahun masa pendidikan. Namun di sisi lain, penambahan ini berpotensi memunculkan beberapa permasalahan antara lain: kebekerjaan, biaya pendidikan, dan usia lulusan. Pemerintah harus memastikan lulusan SMK dapat diserap DUDI, tanpa menambahkan biaya tambahan, dengan keterampilan yang sepadan dengan usia lulusan.

Oleh karena itu, pemerintah harus terlebih dahulu mempersiapkan peluang kerja yang memadai bagi lulusan sebelum mengimplementasikan program pendidikan empat tahun. Pemerintah perlu terlebih dahulu membenahi sistem kerja sama antara sekolah dan DUDI dengan:

1) Melaksanakan kewajiban kepada pemerintah provinsi untuk melakukan kerja sama dengan membentuk kerja sama antara DUDI dan sekolah dalam hal pelaksanaan mutu pembelajaran SMK.

2) Menyelenggarakan program pembuatan kurikulum bersama dengan dinas pendidikan provinsi sebagai mediator, pemerintah ikut duduk bersama tidak hanya sekadar memberikan persetujuan.

3) Menjadikan kerja sama dengan DUDI sebagai persyaratan yang harus dipenuhi setiap bidang keahlian yang dibuka dan diselenggarakan SMK.

4) Melakukan evaluasi tahunan jumlah SMK dan bidang keahlian yang tidak terserap pasar kerja agar dapat dikurangi, bahkan mengajukan bidang keahlian baru yang lebih potensial.

Perubahan masa pendidikan
SMK menjadi empat tahun tentu
akan berpengaruh pada anggaran pendidikan yang harus disiapkan. Oleh karena itu, DPR Rl terutama Komisi $X$ harus terus mengawal perbaikan pendidikan kejuruan dengan memastikan pemerintah menyelesaikan masalah kebekerjaan, skema biaya pendidikan, dan permasalahan kapasitas usia lulusan sebelum mengimplementasikan masa pendidikan empat tahun. Sesuai dengan fungsi anggarannya, Komisi $X$ dapat mengusulkan alokasi anggaran yang lebih besar, selain juga mendorong DUDI untuk berpartisipasi aktif dalam mengembangkan pendidikan kejuruan.

\section{Daftar Pustaka}

Ajzen, I. \& Fishbein, M. (2005). The influence of attitudes on behavior. Dalam D. Albarracín, B. T. Johnson, \& M. P. Zanna (Eds.), The handbook of attitudes. Mahwah, $\mathrm{NJ}$ : Erlbaum.

Albarracin, D., Sunderrajan, A., Lohmann, S., Chan, M. S., \& Jiang, D. (2018). The Psychology of Attitudes, Motivation, and Persuasion. Dalam D. Albarracin \& B. T. Johnson (Eds.), Handbook of Attitudes. United Kingdom: Routledge.

Allport, G. W. (1935). Attitudes. Dalam C. Murchison (Ed.), Handbook of Social Psychology. Worcester: Clark University Press.

Asian Development Bank [ADB]. (2016, Desember). Indonesia: Vocational Education Strengthening Project. Diakses dari https://www.adb.org/sites/default/ files/evaluation-document/219466/files/ pvr-493.pdf.

Badan Pusat Statistik [BPS]. (2018). Persentase Usia Muda (15-24 Tahun) Yang Sedang Tidak Sekolah, Bekerja Atau Mengikuti Pelatihan. Diakses dari https://www.bps. go.id/dynamictable/2018/05/18/1328/ persentase-usia-muda-15-24-tahunyang-sedang-tidak-sekolah-bekerja-ataumengikuti-pelatihan-2015---2018.html.

Badan Pusat Statistik [BPS]. (2020). Laporan Bulanan Data Sosial Ekonomi (Edisi 125). Diakses dari https://www.bps.go.id/ publication/download.html? nrbvfeve=M2 
M5NWMwMjcyMjJmNGRkNTNiMjQ4ZDB $m \& x z m n=a H R 0 c H M 6 L y 93 d 3 c u Y n B z L m d$ vLmIkL3B1YmxpY2F0aW9uLzIwMjAvM TAvMTIvM2M5NWMwMjcyMjJmNGRk NTNiMjQ4ZDBmL2xhcG9yYW4tYnVsYW5 hbi1kYXRhLXNvc2lhbC1la29ub21pLW9rd G9iZXItMjAyMC5odG1s\&twoadfnoarfeau $\mathrm{f}=$ MjAyMC0xMSOwMiAyMToyMDowNw \%3D\%3D.

Damarjati, T. (2016, September 2). Konsep Pembelajaran di Sekolah Menengah Kejuruan. Diakses dari http://psmk. kemdikbud.go.id/konten/1869/konseppembelajaran-di-sekolah-menengahkejuruan.

Dharmaningtyas \& Subkhan, E. (2012). Manipulasi Kebijakan Pendidikan. Jakarta: Resist Book.

Direktorat Jenderal Pembinaan SMK [Dit. PSMK]. (2017). Strategi Implementasi Revitalisasi SMK (10 Langkah Revitalisasi SMK). Jakarta: Kementerian Pendidikan dan Kebudayaan.

Direktorat Jenderal Pembinaan SMK [Dit. PSMK]. (2018). Kilasan Dua Tahun Revitalisasi Sekolah Menengah Kejuruan September 2016-2018. Jakarta: Kementerian Pendidikan dan Kebudayaan.

Direktorat Jenderal Pembinaan SMK [Dit. PSMK]. (2019a). Turbulensi Pendidikan Vokasi di Era Disrupsi 4.0. Jakarta: Kementerian Pendidikan dan Kebudayaan.

Direktorat Jenderal Pembinaan SMK [Dit. PSMK]. (2019b). Analisis Potensi dan Permintaan (Demand) Pekerja Lulusan SMK Menurut Bidang Keahlian Lulusan SMK di Tingkat Provinsi. Jakarta: Kementerian Pendidikan dan Kebudayaan.

Hoeckel, K. (2008). Costs and Benefits in Vocational Education and Training. Diakses dari http://www.oecd.org/education/ innovation-education/41538706.pdf.

Jain, V. (2014). 3D Model of Attitude. International Journal of Advanced Research in Management and Social Sciences, 3(3).

Joy, M. \& Mathew, A. (2018). Emotional Maturity and General Well-being of Adolescents. IOSR Journal of Pharmacy, 8(5), 01-06.
Kamdi, W. (2017). Revitalisasi SMK: Mendongkrak Unggulan Nasional. Diakses dari https://psmk.kemdikbud. go.id/konten/2637/revitalisasi-smkmendongkrak-unggulan-nasional.

Kementerian Pendidikan dan Kebudayaan [Kemendikbud]. (2016). Revitalisasi Pendidikan Vokasi Kementerian Pendidikan dan Kebudayaan. Jakarta: Kementerian Pendidikan dan Kebudayaan.

Kementerian Pendidikan dan Kebudayaan [Kemendikbud]. (2019). Data Pokok SMK. Diakses dari http://datapokok.ditpsmk. net/.

Kementerian Keuangan [Kemenkeu]. (2019). Nota Keuangan beserta RAPBN 2019 (Buku II). Diakses dari https://www. kemenkeu.go.id/media/10377/notakeuangan-dan-rapbn-2019.pdf.

Khurniawan, A. W. \& Haryani, T. (Ed.). (2016). SMK dari Masa ke Masa. Jakarta: Kementerian Pendidikan dan Kebudayaan.

Khurniawan, A. W. \& Majid, M. A. (2019). Analisis Ketercukupan Pembiayaan Pendidikan Sekolah Menengah Kejuruan. Vocational Education Policy, White Paper, 1(2).

Kriyantono, R. (2014). Teknik Praktis Riset Komunikasi (Edisi Pertama). Jakarta: Kencana.

Kumparan. (2020a, Juni 11). Kemendikbud Akan Ubah Masa Studi SMK Jadi 4 Tahun. kumparan.com. Diakses dari https:// kumparan.com/millennial/kemendikbudakan-ubah-masa-studi-smk-jadi-4-tahun1tahxQOTmpT/full.

Kumparan. (2020b, Juni 11). kumparan. com. Diakses dari https://kumparan. com/millennial/polling-kamu-setuju-jikamasa-studi-smk-diubah-jadi-4-tahun1tb3apyhBkC/full.

Miles, M. B. \& Huberman, A. M. (1984). Qualitative Data Analysis: A Sourcebook of New Methods. Beverly Hill: Sage Publications.

Nurmala, Rahman, F., Nugroho, A., Erlyana, N., Laily, N., \& Anhar, V. Y. (2018). Promosi Kesehatan. Surabaya: Airlangga University Press. 
Panitia Kerja Pendidikan Vokasi Komisi X [Panja Pendidikan Vokasi Komisi X]. (2020). Laporan Panitia Kerja Pendidikan Vokasi Komisi X DPR RI: Masa Persidangan III Tahun Sidang 2019-2020. Diakses dari https://berkas.dpr.go.id/sipinter/files/ sipinter--737-20200728121606.pdf.

P. H., Slamet. (2013) Pengembangan SMK Model untuk Masa Depan. Cakrawala Pendidikan, Th. XXXII(1). Diakses dari https://journal.uny.ac.id/index.php/cp/ article/view/1256/pdf.

Rani, R. (2015). Vocational Maturity in relation to Emotional Maturity and Academic Achievement of Secondary School students. Airo International Research Journal, VI.

Setiawati, D. \& Endrastuty, J. F. (2019). Emotional Maturity of Vocational School Students. Advance, Education and Humanities Research, (387), 350-353.

Slapin, J. (2018). Three Basic Steps of Quantitative Text Analysis. Diakses dari https://www.methodspace.com/threebasic-steps-quantitative-text-analysis/. 


\section{Lampiran}

Tabel Komen Pembaca mengenai Wacana Perubahan Program SMK

\begin{tabular}{|c|c|}
\hline Isu & Komen \\
\hline \multirow[t]{4}{*}{ Kebekerjaan } & $\begin{array}{l}\text { Percuma } 4 \text { tahun di smk tpi ujung }{ }^{2} \text { ny jdi pengangguran. Saya sbg murid smk tdk setuju dgn masa } \\
\text { studi smk jdi } 4 \text { tahun. } \\
\text { (SA, } 17 \text { Juni 2020) }\end{array}$ \\
\hline & $\begin{array}{l}\text { Muncul persaingan antara lulusan smk dengan S1 dalam mencari pekerjaan. Mungkin industri lebih } \\
\text { milih smk karna cost nya minim tapi sisi buruknya makin banyak aja lulusan S1 nganggur.. serba } \\
\text { salah jadinya } \\
\text { (AD, 14 Juni 2020) }\end{array}$ \\
\hline & $\begin{array}{l}\text { Ya ampun... Sekolah empat tahun di smk?,jikalau sekolah lama-lama gitu dan ada kepastian lulur } \\
\text { bisa langsung kerja gak apa2lah... } 5 \text { tahun juga boleh...Saya sebagai mahasiswa yang sudah terlanjur } \\
\text { mendaftar di smk menyesal deh...betul.. Teman temanku yang masuk sma udah lulus kita masih } \\
\text { skolah... } \\
\text { Percaya deh... Kalau sekolah } 4 \text { tahun lamanya pasti smk akan kurang minatnya banyak yang berahli } \\
\text { ke sma } \\
\text { Dampaknya bukan hanya pada skolahnya saja,gurunya akan berkurang maka mungkin sarjana } \\
\text { gurupun akan sia2. }\end{array}$ \\
\hline & Tolong deh untuk pemerintah terkhusus mentri pendidikan. Di kaji ulang yah... $\quad$ (DS, 13 Juni 2020) \\
\hline
\end{tabular}

Percma sklah 4 thun lulus jhuga cari kerja susahnya minta ampun

Pak kementrian jgn cman fokuskan hanya penddikan saja harus jalan sama" perhatikan dulu negara kita blm tllu maju dgn negara lain cba perhatikan ulangan ksian masyarakat yg di desa" jln saja rsak prah PLN juga blm msuk nhi jgn pkir yg tinggi"nya dulu perhatikan ulang kira" smua suh beres ko blm

(EDS, 13 Juni 2020)

Adik ipar saya smk kimia serang banten, 4 tahun. Sdh magang di perusahaan, sdh lulus juga, sdh muter2 nyari kerjaan, yg sesuai jurusannya, g dpt2. Skrg malah jadi sekuriti. Coba klo ada smk jurusan sekuriti, mungkin dia sdh kerja dr pas lulus.

(AB, 13 Juni 2020)

Yah lebih baik pertimbangin dulu tuh lapangan pekerjaan dinegara ini, lulus smk nggak jadi pekerja malah malah jadi pengangguran, persaingan ketat sekarang lulus sarjana aja sulit cari kerja apalagi cuman ijazah smk

(RA, 13 Juni 2020)

Ok seumpama kita turuti aturan pemerintah, tapi jika siswa lulus berani jaminkah kerja semua dengan gaji setara D2 / s1

(AR, 12 Juni 2020)

Diploma udah gak laku pak .. sekarang banyak perusahaan nyarinya S1, kalo smknya 4 tahun mending pilih SMA saja lalu kuliah .. kebanyakan lulusan smk jadi tenaga outsourcing

(MAA, 12 Juni 2020)

Yg 3 tahun aja gak ada lagi lowongan kerja shbs tamat... Apalagi yg 4...buang2 umur anak orang aja... Jgn lah peras rakyat demi berlangsungnya roda ekonomi ASN...kalo memang jaminan tamat 4 tahun lgsg kerja sih oke... sekarang S2 aja banyak terbengkalai alias nganggur... Mau dikemanain umur ank orang... (SN, 12 Juni 2020)

Sudah ada beberapa smk yg menerapkan ini. Di sisi lain, kalau industrinya belum banyak serapan lulusan SMK, percuma juga ditambah waktu pendidikannya. Yang ada malah makin sedikit yang mau masuk SMK, karena sebagian masuk SMK juga bukan karena ingin langsung bekerja.

(I, 12 Juni 2020)

hehe..boleh aja cari solusi..tp yakin ga stlah lulus smk 4th bs kerja?jgn smpe ujung ujungnya nganggur...

pling brpa persen yg llus 4th bs bkerja.

wong yg 3th aja byk yg nganggur cari krja susah...apa2 hrus ada org dalem.

kalo bs si buka jurusan org dalem.

cari solusi yg diterima dimasyarakat lah pak..sy krg setuju.

(HL, 12 Juni 2020)

Buka lowongan pekerjaan di luar negeri sebanyak2nya Karena saya mengalami sendiri setelah lulus smk masuk ke dunia industri harus pake jasa yayasan dan itu bayarnya juga mahal kontrak cuma setahun. Akhirnya saya putuskan jadi TKI di korsel alkhamdulillah. Sekarang jadi TKI pun susah ongkosnya mahal.

(AB, 12 Juni 2020) 


Isu Komen

Yang 3 tahun aja banyak yg bolos apalagi 4 tahun

pembelajaran Kalau cuma menambah waktu belajar tanpa perbaikan kwalitas guru dan peralatan praktikum percuma saja. Heran ya, dari tahun ke tahun pemerintahan +62 gak pernah maju cara berfikirnya. SMK di Indonesia itu kekurangan guru berkwalitas yg benar bernar berkeahluan di bidangnya. Kalau yg bergelar S1 atau S2 mah banyak. Itu akibat kesalahan pemerintah yg hanya mementingkan ijasah dalam rekrutmen guru. Percaya dah, urusan gelar negeri +62 gak kalah dengan negara lain, tapi kalau menyangkut kemampuan kita akan miris. Itulah sebabnya lembaga lembaga les dan keterampilan banyak bertumbuhan sebagai akibat kegagalan dunia pendidikan di negeri +62. IKIP dibubarkan diganti dengan Universitas umum. Seharusnya dijadikan sekolah ikatan dinas dengan rekrutmen dan pendidikan yg lebih bagus. Hadeeeeh, ini malah yg gak penting dan gak perlu malah terus saja dilanjutkan jadi sekolah kedinasan. Harusnya dibubarkan karena sdh banyak perguruan tinggi yg mengelola. Amit amit ini negeri +62

(MM, 13 Juni 2020)

Kunci paling utama adalah pada tenaga pendidik dan sistem kurikulumnya. Sistem kurikulum sempurna tetapi tidak di dukung SDM juga sama saja. Begitu juga sebaliknya, jika SDM baik tetapi tata kelola pendidikannya buruk, maka akan mematikan para guru yang sebetulnya mempunyai bakat terpendam.

(ZM, 12 Juni 2020)

Tidak setuju!!!!!

Zonasi saja sudah membuat pusing. Saya dari SMP favorit dan menempuh 9km untuk sekolah tiap hari naik angkutan umum ,desak-desakan.Lalu tiba-tiba zonasi 3tahun itu serasa sia-sia, memutuskan masuk SMK karena keadaan, jika saya daftar SMA meski nilai saya tinggi tidak menjamin diterima di SMA yang saya inginkan. Di daerah saya daerah industri isinya cuman pabrik dan polusi, tapi sekolah SMA tidak ada, adapun satu tapi sangat tidak layak.

Lalu SMK 4tahun....tidak kah berfikir peraturan baru ini tidak adil ?Terkesan terlalu dipaksakan. Setidaknya kembangkan pembangun pendidikan di Indonesia, bangun sekolah di daerah-daerah. Di daerah pelosok sana lulus SMK saja sudah membanggakan, seorang wanita merantau keluar kota jadi pembantu itu sudah hebat.

Sedangkan yang lain berfikir

"Saya sekolah untuk di kemudian hari cari kerja mudah !"

Namun saya dan teman, kami menempuh $9 \mathrm{~km}$ itu.

"Saya sekolah demi negara ,saya harus selah di sekolah terbaik."

Dan sebenarnya sekolah favorit itu tidak ada, yang membedakan pola pikir muritnya, kami oktimis belajar. Karna ini sudah semestinya sebagai pelajar.

(FT, 14 Juni 2020)

Bagus saja sama dengan sekolah kejuruan analis $80 \%$ siswanya diterima bekerja,tinggal sistemnya diubah.klau sekolah analis pake sistem DO jadi klau muridnya tidak berkompeten yaah dikeluarkan bisa diteruskan ke sekolah umum negeri atau swasta yang mau menerima tidak ada masalah saya pikir,hal ini dilakukan demi menciptakan tenaga kerja yang handal dan berkuwalitas....lanjutkan pak menteri (AG,12 Juni 2020)

Yang sangat mendesak adalah Isi materi kurikulum dibenahi dan ditambah peralatan laboratorium untuk jadikan lulusan smk yang expert.

(PI, 12 Juni 2020)

Peningkatan Saya slaku lulusan Smk stuju slama bertujuan meningkatkan kompentensi keahlian siswa itu bagus kompetensi saya berharap ada kurikulum sebelum magang smk memiliki kerjasama pelatihan dgn industri2 terkait jadi siswa dpat pengetahuan dan ketrampilan yg nyata dan dpat cepat beradaptasi dgn dunia industri sehingga memiliki kontribusi sesuai yg diharapkan smoga sukses..

(AS, 12 Juni 2020)

Mantapp ,jdi bisa PKL 2 kali klo bisa $\hat{\theta}$

(A, 11 Juni 2020)

bagus dong

bisa pkl 2 kali yaahahaha

(AWP, 11 Juni 2020)

Emang kalo di tambah 1 tahun di jamin apa? Biar kerja bagus ,biar pinter ,ituu semuaa balik lgi ke siswa nya

(S, 12 Juni 2020)

Saya Yakin akan makin banyak yg putus Sekolah bila terjadi Rencana ini, karena Apa? Boros materi, tambah Jenuh belajar, dan membosankan, dll.Rencana dungu. (FJ, 12 Juni 2020)

Kualifikas 4 TAHUN DAPET GELAR SETARA D1 ATAU D2 KALIAN PUNYA KOMPETENSI .. MAU LU TERUS TERUSAN DIBAYAR MURAH?? (DA, 15 Juni 2020)

Klo memang sekolah 4 tahun setingkat $D 1$ tolong begitu lulus SMK beri gelar D1 yaitu $A$. $P$

(AD, 13 Juni 2020) 


\begin{tabular}{ll}
\hline Isu & \multicolumn{1}{c}{ Komen } \\
\hline \begin{tabular}{l} 
4th setara D1, jika 5th setara D2 jika silabusnya mengikuti jenjangnya. Dan semoga masing2 SMKnya \\
sudah menjalin kerjasama dengan instansi dan MENAKER sehinga penyaluran dan kapasitanya dapat \\
berimbang. Koncinya adalah standarisasi. \\
\cline { 2 - 3 }
\end{tabular} & $\begin{array}{l}\text { jd mungkin tambahan waktu ini justru menguntungkan para siswa smk kedepan krn pengalaman kerja } \\
\text { mereka mungkin bisa d bilang lebih banyak d banding S1 untuk bidang studi yg sama }\end{array}$ \\
\hline
\end{tabular}

(AB, 12 Juni 2020)

\begin{tabular}{llr}
\hline $\begin{array}{ll}\text { Praktik Kerja } \\
\text { Lapangan }\end{array}$ & Mantapp ,jdi bisa PKL 2 kali klo bisa $\theta$ & (A, 11 Juni 2020) \\
\cline { 2 - 3 } & $\begin{array}{l}\text { bagus dong } \\
\text { bisa pkl } 2 \text { kali yaahahaha }\end{array}$ & (AWP, 11 Juni 2020) \\
\hline
\end{tabular}

Lebih klo tau Bkl 4taun mending sma saja:( $\quad$ (CZ, 12 Juni 2020)

$\begin{array}{lll}\text { memilih } & \text { Klw smk di buat } 4 \text { tahun SMA juga dong pasti klw kayal gitu banyak yang akan ke sma bukan ke smk } \\ \text { sekolah } & \end{array}$

menengah

atas (SMA)

Pasti banyak yg pilih SMA lah pak, tapi menurutku sih 3tahun sudah cukup sudah banyak pengalaman yang didapatkan, lah SMA?? $\quad$ (Z ST, 13 Juni 2020)

Kalau seperti itu adanya berarti ijazah SMK harus dapat nilai lebih dari SMA dong, dalam artian di dunia kerja SMK lebih dibutuhkan karena dianggap berpengalaman? (PN, 12 Juni 2020)

coba ditekankan nanti yang mau masuk smk, harus benar-benar yang pengen masuk industri dan pengen belajar, karena title nya bukan setara sma lagi, tapi d1 atau d2 (MA, 12 Juni 2020)

Pembiayaan Sangat berat dengan biaya sekolah, sangat berat nanti dpt krj gaji kecil pas pasan...kalau pengannguran, 3 th sudah lama , tambah lagi kuliah, dan biaya nya (MA, 12 Juni 2020)

Kasian yang pembayaran mahal pakk mereka pasti akan sangat keberatan (MH, 12 Juni 2020)

Gak kelamaan pak mentri?apalgi kalAu prkatek lapanagan sama industri..bayarnya cukup mahal... pak...sekali praktek harus bayar 800 rb...oalah..pak..pak.. (YG, 12 Juni 2020)

Tua di bangku sekolah pak kemendikbud.. Ampun dah biaya sekolah makin bengkak (-5)

(AS, 12 Juni 2020)

Haduuh pak mentri sekolah 3th aja kadang spp telat belom buat jajan atau uang bensin pak Coba berfikir pola masyarakat bawah

Jangan pnya gagasan yg kuran efektif apa asn pingin naik gaji jadi masyarakat kecil yg di korbankan

(AB, 12 Juni 2020)

Saya tidak setuju.Karana itu akan sangat memberatkan terutama bagi para siswa dan orang tua.Saya aj contohnya sekolah smk tujuannya setelah lulus bisa kerja.Nyatanya kakak kelas dan teman teman saya yang lululus aja sulit cari kerja.Terutama melamar pekerjaan di berbagi tempat udah banyak saingannya.Malah sekolahnya di tambah lama.Buat biaya sekolah udah kuwalahan lulus belum tentu langsung dapet Dah lah dunia apa ini.... lihatlah orang orang disepanjang jalan dan para pedagang serta pekerjaaan seeabutan, dan juga semua orang kamu ketahui.Coba tanya saja bagai mana pengalaman mereka selama cari kerja mondar mandir,bolak balik,melamar dapat dipecat dan lain lain.Kamau akan tau betspa menyakitkannya hidup ini. (WW, 12 Juni 2020)

Janganlah ,akan memberatt juga ke orang tua karna bayaran,emang nyari uang gampang kaya metik daun

(S, 12 Juni 2020)

Nyiksa orang tua murid buat bayar sekolah nya...

(AR, 12 Juni 2020)

Gada akhlak keluarga saya dah susah cari utang Sanah sini buat sekolah di tambah lagi 1 tahun lagi iya kalo di sekolah gurunya bener bener mau ngajar satu satu buat praktek kedepan gurunya juga idiot pilih pilih murit yang goblok di biarin yang pinter di depanin,saya sekolah dah pengen lulus tinggal kelas 3 ini pengen di tambah satu tahun lagi jadi dua tajun lagi hadeh pak bapak menjamin saya dapat pekerjaan tinggi gajih bisat tidak saya sekolah tidak dapat ilmu gara gara gurunya milih milih murit akhir nya saya ke bengkel orang ikut orang saya pengen cepet cepet lulus karna saya kasian dengan ekonomi keluarga saya yah kalo bapak mau bayarin makan saya sekolah saya ngasih sangu saya uang bensin saya nggak papa nggak keberatan saya malah seneng saya

(BK, 12 Juni 2020)

SY TDK SETUJU pak..gila SMK tambah 1 thn pikir2 pak...km sekolah byr pak,buat byr skolah aja setengah mati cari sini cari sn ini malah mao tambah 1 thn ...ingat pak ini indonesia jgn smkan dgn luar negeri..apa di jamin skolah 4 thn lgsung dpt kerjaan dan gaji besar..sekolah kejuruan jgn di kutak katik pak..yg hrs di perhatikan pelajaran yg tdk PENTING boleh di kurang2in ini skolah bw tas kayak mao pindah rmh pelajaran byk banget

(RA, 12 Juni 2020) 


\begin{tabular}{|c|c|}
\hline Isu & Komen \\
\hline & $\begin{array}{l}\text { Gk setuju karna bayaran bkl brtmbh lg pa ngotak dong,org tua banting tulang buat sklhin eh mlh di } \\
\text { thmbh lg sthn } \\
\text { (SS, } 12 \text { Juni 2020) }\end{array}$ \\
\hline & $\begin{array}{l}\text { Mai-mainlah pak ke desa kami....biar tau gmna rakyat bawah cari duit buat nyekolahin anaknya.......4 } \\
\text { thn bolehlah pak...serah... } \\
\text { (FA, 12 Juni 2020) }\end{array}$ \\
\hline & $\begin{array}{l}\text { Kalo biaya pendidikan smk nya di gratiskan atau gk diberi subsidi untuk siswa yang kurang mampu, } \\
\text { baru bisa rencana nya terwujud. Toh banyak keuntungan buat smk bisa meluluskan d1 siswa nya } \\
\text { Kalo biaya pendidikan smk nya di gratiskan atau gk diberi subsidi untuk siswa yang kurang mampu, } \\
\text { baru bisa rencana nya terwujud. Toh banyak keuntungan buat smk bisa meluluskan d1 siswa nya } \\
\text { (MD, } 12 \text { Juni 2020) }\end{array}$ \\
\hline & $\begin{array}{l}\text { Kami sekolah. Bayar pakai duit hasil keringat kedua orang tua kami...mereka sudah banting tulang } \\
\text { nyekolahin eh malah mau di tambah 4tahun... bapak punya hati gak sih } \\
\text { (AR, 11 Juni 2020) }\end{array}$ \\
\hline & Sangat kecewa jika itu terjadi kami sekolah bayar pak \\
\hline & $(\mathrm{SH}, 11$ Juni 2020) \\
\hline \multirow[t]{5}{*}{ Usia } & apa apan Kga kga 4 tahun lagi tua di sekolah gua kalo bgtu \\
\hline & $\begin{array}{l}\text { Tua di bangku sekolah pak kemendikbud.. Ampun dah biaya sekolah makin bengkak (A) } \\
\text { (AS, } 12 \text { Juni 2020) }\end{array}$ \\
\hline & $\begin{array}{l}\text { Bner banget,gak semua org yg masuk SMK ingin langsung bekerja,saya aja masuk smk tapi tetap } \\
\text { ingin kuliah } \\
\text { (SI, } 12 \text { Juni 2020) }\end{array}$ \\
\hline & Kelamaan klo 4 tahun kok $\Theta$ \\
\hline & Bgmn kl lulusan SMK mau kuliah.. Jd bingung? Langsung tingkat $2 . . .$. \\
\hline
\end{tabular}

Sumber: https://kumparan.com/millennial/kemendikbud-akan-ubah-masa-studi-smk-jadi-4-tahun-1tahxQOTmpT 